\title{
Pengaruh Model Pakem Berbasis Tri Hita Karana terhadap Keterampilan Menulis
}

\author{
Ni Nym Chintya Pradnyawathi ${ }^{1 *}$, Gst Ngr Sastra Agustika ${ }^{2}$ \\ ${ }^{12}$ Jurusan Pendidikan Guru Sekolah Dasar, FIP, Universitas Pendidikan Ganesha, Indonesia
}

\author{
A R T I CLEINFO \\ Article history: \\ Received 18 December \\ 2018 \\ Received in revised form \\ 30 December 2018 \\ Accepted 15 January 2019 \\ Available online 20 \\ February 2019
}

\section{Kata Kunci:}

PAKEM, Tri Hita Karana

Keterampilan Menulis

Keywords:

PAKEM, Tri Hita Karana

Writing Skill

\begin{abstract}
A B S T R A K
Penelitian ini bertujuan untuk mengetahui pengaruh model PAKEM berbasis tri hita karana terhadap keterampilan menulis siswa kelas IV SD Gugus Letkol Wisnu Denpasar Utara Tahun Ajaran 2017/2018. Jenis penelitian ini adalah eksperimen semu menggunakan desain rancangan kelompok non-ekuivalen. Seluruh siswa kelas IV SD Gugus Letkol Wisnu Denpasar Utara Tahun Ajaran 2017/2018 yang banyaknya 330 orang siswa yang dijadikan populasi penelitian. Sampel ditentukan dengan teknik sampel kelompok yaitu mengacak kelas, sehingga diperoleh kelas IV SD Negeri 3 Peguyangan sebagai kelompok eksperimen sebanyak 38 orang dan kelas IV B SD Negeri 1 Peguyangan sebagai kelompok kontrol sebanyak 43 orang. Data hasil keterampilan menulis dikumpulkan dengan instrumen berupa tes uraian berjumlah 1 butir tes yang telah divalidasi. Data keterampilan menulis dianalisis dengan uji-t polled varian. Hasil analisis menunjukkan bahwa terdapat perbedaan yang signifikan keterampilan menulis kelompok siswa yang dibelajarkan menggunakan model PAKEM berbasis tri hita karana dengan kelompok siswa yang dibelajarkan melalui pembelajaran konvensional pada siswa kelas IV SD Gugus Letkol Wisnu Denpasar Utara Tahun Ajaran 2017/2018. Hal tersebut dibuktikan dengan hasil $t_{\text {hitung }}=4,278>t_{\text {tabel }}(a=0,05,79)=1,990$. Dengan demikian dapat disimpulkan bahwa model PAKEM berbasis tri hita karana berpengaruh secara signifikan terhadap keterampilan menulis siswa kelas IV SD Gugus Letkol Wisnu Denpasar Utara Tahun Ajaran 2017/2018.
\end{abstract}

A B S T R A C T

This research aims to know the influence of the PAKEM model based tri hita karana against writing skills grade IV Gugus Letkol Wisnu North Denpasar District academic year 2017/2018. This type of research is a quasi experimental with non-equivalent group design. The population of this study are all students of grade IV Gugus Letkol Wisnu North Denpasar District academic year 2017/2018 with 330 students. The sample were taken by group and the control group sample technique by randomizing the class. The determination of experimental group and the control group was taken by lottery so that class IV SD Negeri 3 Peguyangan as experiment group as 38 people and class IV B SD Negeri 1 Peguyangan as the control group as 43 people. Results of the data collected with the writing skills of the instrument in the form of the test description amounted to 1 grain of the tests have been validated. Data were analyzed with the writing skills test-t polled variants. The results of the analysis show that there is a significant difference in the writing skills of groups of students who are in learning using the PAKEM model based tri hita karana concept with a group of students learning through conventional dibelajarkan at grade IV Gugus Letkol Wisnu North Denpasar District academic year 2017/2018. It is proved by the results of a $t_{\text {hitung }}=4.278>t_{\text {tabel }}(\alpha=0.05,79)=1.990$. Thus it can be concluded that the PAKEM model based tri hita karana effect on the writing skills grade IV Gugus Letkol Wisnu North Denpasar District academic year 2017/2018.

\footnotetext{
${ }^{1}$ Corresponding author.

E-mail addresses: chintya.pradnyawathi@undiksha.ac.id (Ni Nym Chintya Pradnyawathi)
} 


\section{Pendahuluan}

Kualitas pendidikan yang berlangsung saat ini perlu adanya upaya yang dilakukan secara konvensional ataupun inovatif, salah satunya adalah perbaikan kurikulum. Kurikulum merupakan salah satu indikator di dalam menentukan keberhasilan suatu pendidikan. Kurikulum pada Sekolah Dasar/Madrasah Ibtidaiyah yang telah dilaksanakan sejak tahun ajaran 2013/2014 disebut Kurikulum 2013. Kota Denpasar merupakan salah satu daerah yang telah melaksanakan Kurikulum 2013 di tingkat SD, SMP, SMA/K secara merata. Kurikulum 2013 merupakan aktualisasi kurikulum dalam pembelajaran dan pembentukkan kompetensi serta karakter siswa (Mulyasa, 2015:99). Kurikulum 2013 bertujuan untuk mempersiapkan manusia Indonesia agar memiliki kemampuan hidup sebagai pribadi dan warga negara yang beriman, produktif, kreatif, inovatif, dan afektif serta mampu berkontribusi pada kehidupan bermasyarakat, berbangsa, bernegara, dan peradaban dunia (Permendikbud No. 57 Tahun 2014 lampiran I). Setiap sekolah diharapkan nantinya mampu melaksanakan Kurikulum 2013 secara merata di Indonesia. Menurut Suharman (2011) Pendidikan pada hakekatnya adalah usaha untuk memanusiakan manusia. Hakekat manusia itu sendiri selalu berkembang. Sistem pendidikan pada masa lampau tidak mampu menghasilkan sumber daya manusia yang sesuai dengan zaman modern saat ini. Pemerintah berupaya meningkatkan mutu pendidikan mulai dari jenjang sekolah dasar sampai perguruan tinggi. Salah satunya yaitu jenjang pendidikan sekolah lanjutan tingkat atas. Solusi untuk meningkatkan mutu pendidikan yakni mengaktifkan dan mengefisienkan proses belajar di sekolah termasuk didalamnya penggunaan pendekatan yang tepat.

Menurut Khair (2018) pembelajaran merupakan kegiatan pendidikan di sekolah yang berfungsi membantu pertumbuhan dan perkembangan anak agar tumbuh ke arah positif. Maka cara belajar siswa (subyek belajar) di sekolah diarahkan dan tidak dibiarkan berlangsung sembarangan tanpa tujuan. Melalui sistem pembelajaran di sekolah, anak melakukan kegiatan belajar dengan tujuan akan terjadi perubahan positif pada diri anak menuju kedewasaan. Pembelajaran merupakan proses untuk membantu siswa agar dapat belajar dengan baik. Guru harus menguasi prinsip-prinsip pembelajaran, pemilihan dan penggunaan model pembelajaran, keterampilan menilai hasil-hasil belajar siswa, serta memilih dan menggunakan strategi atau pendekatan pembelajaran. Kondisi eksternal yang harus diciptakan oleh guru menunjukkan variasi dalam pembelajaran dan tidak sama antara jenis belajar yang satu dengan yang lainnya. "Guru harus memiliki pengetahuan yang sangat luas mengenai jenis-jenis belajar, kondisi internal dan eksternal peserta didik, serta cara melakukan pembelajaran yang efektif dan bermakna" (Mulyasa, 2015:100). Pembelajaran efektif dan bermakna siswa perlu dilibatkan secara aktif, karena mereka adalah pusat dari kegiatan pembelajaran serta pembentukan kompetensi, dan karakter. Salah satu upaya dalam menciptakan siswa berdasarkan tujuan pendidikan nasional dari sekolah dasar sampai perguruan tinggi dengan diberikannya pendidikan bahasa Indonesia di sekolah yang berperan dalam pembentukan karakter siswa.

Menurut Farhrohman (2017) pelajaran bahasa Indonesia merupakan salah satu mata pelajaran yang harus diajarkan di sekolah dasar. Bahasa merupakan percakapan atau alat komunikasi dengan sesama manusia. bahasa merupakan alat komunikasi yang menjadi salah satu ciri khas bangsa Indonesia dan digunakan sebagai bahasa nasional. Hal ini yang merupakan salah satu sebab mengapa bahasa Indonesia diajarkan pada semua jenjang pen- didikan, terutama di SD karena merupakan dasar dari semua pembelajaran. Pembelajaran bahasa Indonesia meliputi empat keterampilan berbahasa, yaitu menyimak, berbicara, membaca, dan menulis (Susanto, 2013:241). Penelitian ini hanya membahas keterampilan menulis. Menurut undang-undang Nomor 20 Tahun 2003 tentang Sistem Pendidikan Nasional dan Peraturan Menteri Pendidikan Nasional Nomor 22 Tahun 2006 tentang standar isi, secara garis besar pembelajaran bahasa Indonesia di Sekolah Dasar diarahkan untuk meningkatkan keterampilan peserta didik untuk berkomunikasi dalam bahasa Indonesia dengan baik dan benar, baik secara lisan maupun tulis, serta menumbuhkan apresiasi terhadap hasil karya kesastraan manusia Indonesia.

Berdasarkan observasi yang telah dilakukan pada tanggal 09 Januari 2018 di seluruh sekolah dasar yang berada di Gugus Letkol Wisnu Denpasar Utara diperoleh hasil nilai ulangan akhir semester 1 pada keterampilan menulis muatan materi bahasa Indonesia, yaitu dari 330 siswa kelas IV, 13 siswa yang mendapat nilai A, 59 siswa yang mendapat nilai B, 147 siswa yang mendapat nilai C, 81 siswa yang mendapat nilai D. Kriteria Ketuntasan Minumum (KKM) untuk keterampilan menulis yang diharapkan oleh SD di seluruh Gugus Letkol Wisnu rata-rata adalah B. Jadi dari data tersebut sebanyak 72 siswa yang sudah mencapai KKM, sedangkan 258 siswa yang belum mencapai KKM. Ini memperlihatkan bahwa $79 \%$ siswa memiliki kompetensi pengetahuan matematika yang berada dibawah KKM dan hanya 21\% yang mampu mencapai KKM. 
Banyak faktor yang melatarbelakangi hal tersebut, diantaranya pembelajaran bahasa Indonesia di SD selama ini, belum mengarahkan siswa untuk mengembangkan keterampilan menulis untuk berkomunikasi, karena yang dipelajari lebih banyak bahasa sebagai ilmu bukan sebagai alat komunikasi. Siswa hafal bagaimana cara membuat karya tulis, tetapi ketika harus menulis mereka bingung dari mana harus memulai. Selain itu, banyak siswa beranggapan bahwa pembelajaran menulis menyita pemikiran mereka dan minat siswa kurang terhadap pembelajaran menulis terutama dalam menulis deskripsi. Hal inilah yang menjadikan siswa kurang melatih keterampilan dalam menulis deskripsi.

Untuk mencapai tujuan mengembangkan keterampilan menulis, diperlukan pembelajaran yang mampu membuat siswa lebih aktif, kreatif, efektif dan menyenangkan. Pembelajaran tersebut akan melatih imajinasi siswa untuk menuangkan ke dalam sebuah tulisan. Sesuai dengan pendapat Susanto (2013:248-249) menyatakan "keterampilan menulis merupakan kegiatan menuangkan ide atau gagasan yang ada di pikiran kita, menuangkan isi hati kita melalui bahasa tulisan sehingga dapat dibaca dan dipahami orang lain. Berdasarkan pendapat tersebut, dengan adanya terlatihnya imajinasi siswa melalui pembelajaran yang menarik siswa akan bebas menuangkan ide-idenya.

Keterampilan menulis seseorang ditunjukkan oleh kemampuannya menuangkan gagasan secara terorganisasi dengan baik melalui tulisan. Keterampilan menulis adalah keterampilan yang paling kompleks. Menurut Tarigan (2013:3) "keterampilan menulis merupakan suatu keterampilan berbahasa yang dipergunakan untuk berkomunikasi secara tidak langsung, tidak secara tatap muka dengan orang lain". Dalman (2016) menyatakan keterampilan menulis merupakan suatu keterampilan yang bermanfaat sebagai kegiatan komunikasi penyampaian pesan, yang dilakukan secara tertulis dengan menggunakan bahasa tulis sebagai alat atau medianya. Susanto (2013:248-249) berpendapat "keterampilan menulis merupakan kegiatan menuangkan ide atau gagasan yang ada di pikiran kita, menuangkan isi hati kita melalui bahasa tulisan sehingga dapat dibaca dan dipahami orang lain. Sedangkan Cahyani (2015:41) mengatakan "keterampilan menulis sebagai sebuah kegiatan produktif, kreatif, dan ekspresif, ada wujudnya, dan ada jelmaan bentuknya yang secara visual dapat dibaca". Berdasarkan paparan tersebut dapat disimpulkan bahwa keterampilan menulis merupakan kegiatan penyampaian pesan yang dibuat secara tertulis dengan menghasilkan sesuatu tulisan berbentuk secara visual yang dapat dibaca oleh semua orang. Proses mengembangkan keterampilan menulis yang dimiliki siswa perlu adanya suatu pembelajaran yang menyenangkan dirancang oleh guru, siswa akan berpartisipasi secara aktif dalam kegiatan pembelajaran serta akan merasa senang pada saat proses belajar mengajar berlangsung. Model pembelajaran keterampilan menulis bahasa Indonesia diupayakan agar mampu mengembangkan potensi siswa, sehingga pembelajaran menjadi aktif, kreatif, efektif, dan menyenangkan.

Salah satu model pembelajaran yang menuntut aktivitas dan kreativitas siswa adalah model PAKEM. PAKEM merupakan singkatan dari Pembelajaran Aktif, Kreatif, Efektif, dan Menyenangkan. Istilah PAKEM dikembangkan dari istilah AJEL (Active Joyful and Effective Learning (Asmani, 2011:63). Pada dasarnya, landasan-landasan teori yang digunakan PAKEM dengan pengambilan teori-teori tentang active learning atau pembelajaran aktif. Menurut Asmani (2011:56) menyatakan "model pembelajaran yang aktif, kreatif, efektif, dan menyenangkan, yang disingkat dengan PAKEM (joyful learning)". Rusman (2014:322) menyatakan "pembelajaran PAKEM diharapkan berkembangnya berbagai macam inovasi kegiatan pembelajaran untuk mencapai tujuan pembelajaran yang partisipatif, aktif, kreatif, efektif, dan menyenangkan". Selanjutnya Widyaningsih (2014:4) mengatakan bahwa "pembelajaran yang tertuju pada bagaimana cara menggunakan metode serta mengelola pembelajaran yang mengajak siswa untuk lebih mengaktifkan diri dalam berkreatifitas dalam situasi yang menyenangkan". Berdasarkan tiga pendapat tersebut dapat dirangkum bahwa model pembelajaran PAKEM adalah model pembelajaran yang berpusat pada anak dan melibatkan siswa melalui pembelajaran aktif, kreatif, efektif, dan menyenangkan agar siswa terus termotivasi untuk belajar dengan sendirinya tanpa diperintah oleh guru.

Model PAKEM dalam penerapannya didasarkan pada tri hita karana. Di era globalisasi seperti sekarang ini kemajuan IPTEK dan pengaruh nilai sosial budaya dari negara barat sangat berpengaruh pada pola pikir dan prilaku sebagian masyarakat terutama generasi muda, sehingga diperlukan suatu pembelajaran yang tetap memunculkan nilai kearifan lokal, salah satunya tri hita karana. Menurut Ani (2017) dewasa ini dapat kita rasakan sendiri bahwa telah terjadinya ketidak harmonisan antara manusia dengan lingkungan maupun sesamanya, hal tersebut tentu menjadi sorotan bagi peneliti, maka dirasa perlu untuk mengenalkan konsep Tri Hita Karana kepada peserta didik selaku penerus bangsa. Tri Hita Karana itu sendiri merupakan salah satu kearifan lokal yang mengemukakan tentang hubungan baik manusia dengan Tuhan, sesama manusi, dan lingkungan tempat tinggalnya. Konsep Tri Hita Karana mengajarkan manusia untuk senantiasa menjaga keharmonisan di dunia mulai dari diri sendiri dan segala sesuatu yang ada di sekitarnya. "Konsep tri hita karana inilah yang dijadikan dasar untuk mengajarkan manusia agar mampu mengupayakan hubungan yang harmonis dengan Tuhan, dengan sesama manusia dan dengan alam lingkungannya" (Wiana, 2007:5-6). Astami (2016:4) menyatakan "tri hita karana terdiri 
dari 3 kata yaitu tri, hita dan karana. Tri berarti tiga, hita berarti kegembiraan, sejahtera sedangkan karana berarti penyebab sehingga tri hita karana berarti tiga buah unsur penyebab dari kebahagiaan". Wirawan (2011:2) menyatakan "pengertian tri hita karana adalah tiga hal pokok yang menyebabkan kesejahteraan dan kemakmuran hidup manusia". Berdasarkan pendapat tersebut dapat disimpulkan bahwa tri hita karana berarti tiga unsur penyebab kebahagiaan dan kesejahteraan manusia yang bersumber dari adanya hubungan yang harmonis antara manusia dengan Tuhan, manusia dengan manusia serta manusia dengan alam.

Salah satu model pembelajaran yang memberikan kesempatan kepada siswa untuk berimajinasi adalah model PAKEM. Model PAKEM berbasis tri hita karana adalah model pembelajaran yang memberikan kesempatan setiap siswa berpartisipasi dalam berbagai aktivitas, kegiatan pembelajaran siswa dalam mengakses berbagai informasi, pengetahuan untuk dibahas dan dikaji dalam proses pembelajaran di kelas serta menciptakan suasana lingkungan belajar yang memadai/kondusif dibarengi dengan pengamalan nilai-nilai kearifan lokal tri hita karana. "Perwujudan tri hita karana dalam umat Hindu di Bali yaitu parhyangan, palemahan, dan pawongan" (Ngurah, 1999:100). Implementasi tri hita karana bagian parhyangan terlihat pada saat guru dan siswa melaksanakan persembahyangan saat mengawali serta mengakhiri pembelajaran. Selain itu dalam mempelajari tema yang bersangkutan, guru mengajak siswa untuk mengucapkan syukur atas karunia Tuhan. Implementasi nilai pawongan sangat terlihat pada saat siswa belajar. Model PAKEM merupakan model pembelajaran yang mengajak siswa menciptakan suasana pembelajaran aktif, kreatif, efektif, dan menyenangkan. Selain itu, dalam model PAKEM mengutamakan kebersamaan siswa dalam menyampaikan pikiran, sehingga siswa akan memiliki imajinasi dalam menulis deskripsi. Implementasi nilai palemahan terlihat dalam suasana belajar siswa yang tidak hanya belajar di dalam kelas tetapi juga menggunakan lingkungan sekitar sebagai sarana belajar. Berdasarkan uraian tersebut, dengan menggunakan model PAKEM berbasis tri hita karana dapat mengarahkan siswa untuk pembelajaran aktif, kreatif, efektif, dan menyenangkan sehingga berpengaruh terhadap keterampilan menulis, tetapi secara empiris perlu dibuktikan kebenarannya.

Berdasarkan uraian tersebut, dilakukanlah penelitian dengan judul Pengaruh Model PAKEM Berbasis Tri Hita Karana Terhadap Keterampilan Menulis Siswa Kelas IV SD Gugus Letkol Wisnu Denpasar Utara Tahun Ajaran 2017/2018.

\section{Metode}

Penelitian ini dilaksanakan pada semester genap di kelas IV SD Gugus Letkol Wisnu Denpasar Utara Tahun Ajaran 2017/2018. Penelitian ini tergolong penelitian kuantitatif dengan rancangan eksperimen kuasi (Quasi-Eksperimental Design). Sugiyono (2014:114) menyatakan "desain ini memiliki kelompok kontrol, tetapi tidak bisa sepenuhnya mengontrol variabel- variabel luar yang mempengaruhi pelaksanaan eksperimen". Selanjutnya Setyosari (2015) menyatakan rancangan eksperimen kuasi digunakan karena dalam pemilihan subjek penelitian, tidak selalu dapat dilakukan pemilihan subjek secara random (individual random). Dalam penetapan random (random assignment), tidak memungkinkan memilih dan memilah subjek sesuai dengan rancangannya, akan tetapi menggunakan kelas atau kelompok subjek yang telah ditentukan oleh sekolah. Berdasarkan pendapat kedua ahli tersebut dapat disimpulkan bahwa rancangan eksperimen kuasi digunakan jika variabel- variabel luar yang mempengaruhi eksperimen tidak sepenuhnya bisa dikontrol serta pemilihan subjek penelitian tidak dapat dilakukan dengan cara pengacakan individu.

Bentuk desain kuasi eksperimen yang digunakan adalah rancangan kelompok non-ekuivalen.

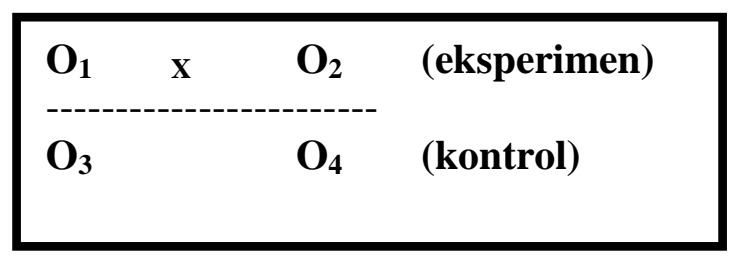

Gambar 1. Desain Eksperimen

(Sumber: Setyosari, 2015:211)

Populasi dari penelitian ini adalah seluruh siswa kelas IV SD Gugus Letkol Wisnu Denpasar Utara Tahun Ajaran 2017/2018 yang terdiri dari 9 kelas dalam 7 sekolah dasar. Jumlah populasi dari penelitian ini adalah 330 orang siswa. 
Teknik pengambilan sampel pada penelitian ini adalah sampel kelompok. Setyosari (2015) mengatakan bahwa teknik sampel kelompok digunakan apabila populasi atau sampel yang tersedia berupa unit-unit rumpun dalam populasi, contohnya menggunakan kelas atau kelompok, dan tidak mungkin mengambil secara acak setiap individual dari setiap kelas. Penentuan sampel penelitian ini tidak dilakukannya pengacakan individu melainkan hanya pengacakan kelas, karena tidak bisa mengubah kelas yang telah ditentukan sebelumnya.

Cara yang digunakan adalah dengan cara pengundian. Cara undian dilakukan dengan menulis semua nama kelas IV di seluruh SD populasi pada masing-masing kertas, kemudian kertas digulung. Ambil satu gulungan kertas, lalu ambil satu gulungan kertas lain, tanpa memasukkan kembali gulungan kertas pertama. Nama-nama SD pada kedua gulungan kertas tersebut merupakan sampel penelitian.

Setelah mengadakan pengundian, diperoleh 2 kelas yakni kelas IVB SD Negeri 1 Peguyangan dan kelas IV SD Negeri 3 Peguyangan. Kelas IV B SD Negeri 1 Peguyangan berjumlah 45 orang siswa dan kelas IV SD Negeri 3 Peguyangan berjumlah 38 orang siswa.

Dalam sebuah penelitian eksperimen perlu dilakukan pengendalian terhadap validitas penelitian yang dapat mempengaruhi hasil penelitian. Terdapat dua ancaman validitas eksperimen yang terdiri atas validitas internal serta validitas eksternal. Penelitian ini validitas internal yang perlu dikontrol terdiri atas karakteristik subyek, lokasi, instrumentasi, testing, sejarah (history) dan kematangan (maturaty). Validitas eksternal mengenai sejauh mana hubungan yang terjadi dapat digeneralisasikan terhadap kategori subyek. Untuk memperoleh validitas eksternal yang tinggi perlu untuk mempertimbangkan karakteristik subyek dengan perlakuan dan setting perlakuan dengan perlakuan yang diperlukan.

Metode yang digunakan dalam pengumpulan data penelitian ini adalah metode tes. Tes yang diberikan kepada siswa berupa tes uraian. Untuk menilai tes keterampilan menulis deskripsi perlu adanya penggunaan rubrik penilaian. Keterampilan menulis deskripsi yang diukur yaitu pada kesesuaian tema, ketepatan isi dalam paragraf, kesesuaian isi dengan judul, ketepatan susunan kaliamat dan diksi (pilihan kata), dan ketepatan penggunaan ejaan dan tata tulis. Dalam penelitian ini untuk menguji kevalidan tes peneliti menggunakan validitas teoritik. Validitas teoritik terdiri dari validitas isi dan validitas konstrak.

Data yang dianalisis pada kedua kelompok adalah gain skor ternormalitas menunjukkan tingkat efektifitas perlakuan daripada perolehan skor pretest dan skor posttest. Menghitung N-Gain dirumuskan oleh Hake (dalam Purwanto,dkk, 2015:132) dilakukan dengan rumus sebagai berikut.

$$
<\mathrm{g}>=\frac{\mathrm{S}_{\text {post }}-\mathrm{S}_{\text {pre }}}{100-\mathrm{S}_{\text {pre }}}
$$

Untuk menginterpretasikan N-Gain, dapat dilihat pada tabel sebagai berikut.

Tabel 1. Kriteria N-Gain

\begin{tabular}{lll}
\hline & N-Gain & Interpretasi \\
\hline$<\mathrm{g}>\geq 0,70$ & Gain tinggi & \\
$0,30 \geq<\mathrm{g}>\geq$ & Gain sedang & \\
$<\mathrm{g}><0,30$ & Gain rendah & \\
\hline
\end{tabular}

(Sumber: Purwanto,dkk, 2015:132)

Metode analisis statistik dapat dibagi menjadi dua, yaitu statistik deskriptif dan statistik inferensial. Data yang disajikan dalam statistik deskriptif adalah perhitungan mean, median, modus, grafik polygon, kemiringan kurva, serta standar deviasi dan variansi. Statistik inferensial adalah penerapan rumus-rumus statistik inferensial untuk menguji hipotesis yang diajukan dalam penelitian dan menarik kesimpulan. Statistik inferensial teridiri dari pengujian prasyarat analisis dan pengujian hipotesis. Uji prasyarat penelitian yang meliputi uji normalitas dan uji homogenitas. Uji Normalitas sebaran data dalam penelitian ini menggunakan metode Kolmogorov-Smirnov. Uji homogenitas variansi dilakukan dengan uji F. Analisis statistik yang digunakan untuk menguji hipotesis penelitian adalah uji beda mean (uji t). Rumus uji-t dengan rumus polled varian. Hasil data yang diperoleh setelah diuji normalitas dan homogenitas akan dilanjutkan dengan menguji hipotesisnya. hipotesis statistik dalam penelitian ini $\mathrm{H}_{0}$ : Tidak terdapat perbedaan yang signifikan keterampilan menulis kelompok siswa yang dibelajarkan menggunakan model PAKEM berbasis tri hita karana dengan kelompok siswa yang dibelajarkan melalui pembelajaran konvensional pada siswa kelas IV SD Gugus Letkol Wisnu Denpasar Utara Tahun Ajaran 2017/2018. 


\section{Hasil dan Pembahasan}

Berdasarkan hasil penelitian yang meliputi model PAKEM berbasis tri hita karana sebanyak 6 kali pada siswa SD Negeri 3 Peguyangan, di akhir penelitian siswa diberikan posttest untuk memperoleh data keterampilan siswa. Setelah memperoleh skor posttest kemudian dicari gain skor yang dinormalisasi dari hasil pretest dan posttest. Maka diperoleh hasil nilai rata-rata kelompok eksperimen yang dibelajarkan menggunakan model PAKEM berbasis tri hita karana adalah 0,49. Letak nilai tengah (median) pada kelompok eksperimen yaitu 0,50 dan nilai yang paling sering muncul (modus) adalah 0,50 dengan frekuensi sebanyak 7. Pada penelitian ini diperoleh variansi $\left(s^{2}\right)=0,033$ dan standar deviasi $(s)=0,18$ pada keterampilan menulis kelompok eksperimen. Distribusi frekuensi data keterampilan menulis kelompok eks-perimen disajikan dalam bentuk grafik polygon sebagai berikut.

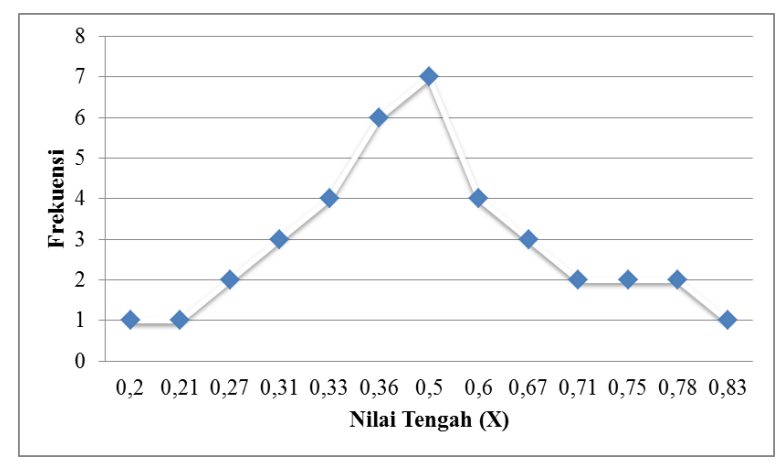

Gambar 2. Grafik polygon Keterampilan Menulis Kelompok Eksperimen

Berdasarkan gambar 2 grafik polygon keterampilan menulis kelompok eksperimen menunjukkan bahwa data yang diperoleh menggambarkan kurva normal. Dapat dilihat pada perhitungan median dan modus yang diperoleh dari pengumpulan data siswa adalah 0,50 . Sehingga tidak terjadi kemiringan kurva yang cenderung menunjukkan negatif dan positif pada data. Nilai yang diperoleh siswa berdasarkan data gain skor ternormalisasi keterampilan menulis kelompok eksperimen menunjukkan yang memperoleh interpretasi gain rendah $(<\mathrm{g}><0,30)=4$ orang siswa, interpretasi gain sedang $(0,30 \geq<\mathrm{g}>)=27$ orang siswa, dan interpretasi gain tinggi $(<\mathrm{g}>\geq 0,70)=7$ orang siswa.

Sementara, pada akhir penelitian siswa kelas IV B SD Negeri 1 Peguyangan diberikan posttest untuk memperoleh data keterampilan menulis siswa. Setelah memperoleh skor posttest kemudian dicari gain skor yang dinormalisasi dari hasil pretest dan posttest. Pada kelompok kontrol diperoleh hasil nilai rata-rata kelompok kontrol yang dibelajarkan melalui pembelajaran konvensional adalah 0,33 . Letak nilai tengah (median) pada kelompok kontrol yaitu 0,30 dan nilai yang paling sering muncul (modus) adalah 0,30 dengan frekuensi sebanyak 6. Pada penelitian ini diperoleh variansi $\left(\mathrm{s}^{2}\right)=0,024$ dan standar deviasi $(s)=0,15$ data keterampilan menulis pada kelompok eksperimen. Distribusi frekuensi data keterampilan menulis kelompok eksperimen disajikan dalam bentuk grafik polygon sebagai berikut.

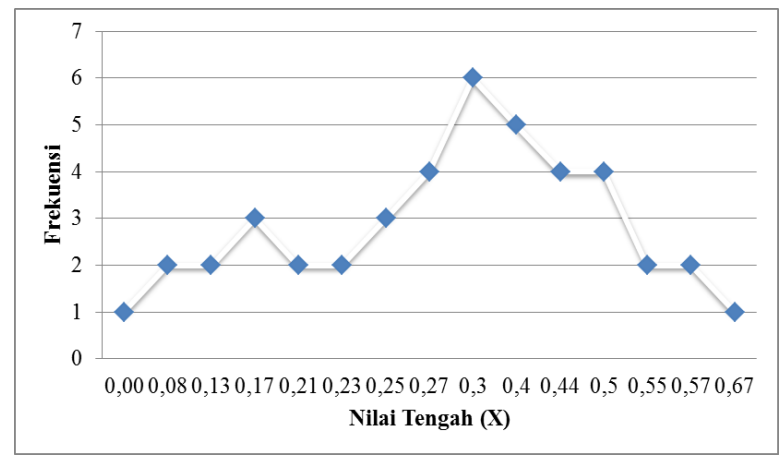

Gambar 3. Grafik polygon Keterampilan Menulis Kelompok Kontrol

Berdasarkan gambar 3 grafik polygon keterampilan menulis kelompok kontrol menunjukkan bahwa data yang diperoleh menggambarkan kurva normal. Dapat dilihat pada perhitungan median dan modus yang diperoleh dari pengumpulan data siswa adalah 0,30 . Sehingga tidak terjadi kemiringan kurva 
yang cenderung menunjukkan negatif dan positif pada suatu data. Nilai yang diperoleh siswa dari data gain skor ternormalisasi keterampilan menulis kelompok eksperimen menunjukkan yang memperoleh peningkatan intepretasi gain rendah $(<\mathrm{g}><0,30)=19$ orang siswa, intepretasi gain sedang $(0,30 \geq<\mathrm{g}>)=$ 24 orang siswa.

Sebelum dilakukan uji hipotesis dengan uji-t, terlebih dahulu dilakukan uji prasyarat analisis data yang meliputi uji normalitas sebaran data dan uji homogenitas variansi. Pada uji normalitas seberan data menggunakan rumus analisis Kolmogorov-Smirnov memperloleh taraf signifikan 5\% $(\alpha=0,05)$ dan $\mathrm{N}=38$ di peroleh nilai tabel Kolmogorov-Smirnov $=0,215$. Hasil uji normalitas sebaran data kelompok eksperimen diperoleh $\mathrm{F}_{\mathrm{T}}-\mathrm{F}_{\mathrm{S}}$ terbesar $=0$,208. Karena $\mathrm{F}_{\mathrm{T}}-\mathrm{F}_{\mathrm{S}}$ terbesar $=0,208<$ nilai tabel KolmogorovSmirnov= 0,215 maka $\mathrm{H}_{0}$ diterima atau $\mathrm{H}_{a}$ ditolak yang berarti data keterampilan menulis kelompok eksperimen berdistribusi normal. Sementara itu, Pada taraf signifikan $5 \%(\alpha=0,05)$ dan $N=43$ di peroleh nilai tabel Kolmogorov-Smirnov= 0,207. Hasil uji normalitas sebaran data kelompok kontrol diperoleh $\mathrm{F}_{\mathrm{T}^{-}}$ $\mathrm{F}_{\mathrm{S}}$ terbesar= 0,154. Karena $\mathrm{F}_{\mathrm{T}}-\mathrm{F}_{\mathrm{S}}$ terbesar= 0,154 < nilai tabel Kolmogorov-Smirnov= 0,207 maka $\mathrm{H}_{0}$ diterima atau $\mathrm{H}_{\mathrm{a}}$ ditolak yang berarti data keterampilan menulis kelompok kontrol berdistribusi normal.

Uji homogenitas variansi dilakukan berdasarkan data keterampilan menulis yang menggunakan data gain skor ternormalisasi kelompok yang dibelajarkan melalui model PAKEM berbasis tri hita karana dengan kelompok siswa yang dibelajarkan melalui pembelajaran konvensional. Jumlah masing-masing kelompok analisis adalah 38 orang siswa untuk kelompok eksperimen dan 43 orang siswa untuk kelompok kontrol.

Pada taraf signifikan $5 \%$ dengan dk untuk pembilang $\mathrm{n}_{1}-1(38-1=37)$ dan dk penyebut $\mathrm{n}_{2}-1$ (431=42) diperoleh $F_{\text {tabel }}=1,69$. Sedangkan dari hasil analisis uji homogenitas variansi diperoleh $F_{\text {hitung }}=1,38$. Karena $\mathrm{F}_{\text {hitung }}=1,38<\mathrm{F}_{\text {tabel }}=1,69$, maka data keterampilan menulis kelompok eksperimen dan keterampilan menulis kelompok kontrol mempunyai variansi homogen.

Karena data yang diperoleh telah memenuhi prasyarat, uji hipotesis dilakukan dengan analisis ujit. Rumus uji-t dengan rumus polled varian.

Adapun kriteria pengujian yaitu $\mathrm{H}_{0}$ ditolak dan $\mathrm{H}_{a}$ diterima jika harga $t_{\text {hitung }}>t_{\text {tabel }}$ sedangkan $\mathrm{H}_{0}$ diterima dan $\mathrm{H}_{\mathrm{a}}$ ditolak jika harga $\mathrm{t}_{\text {hitung }} \leq \mathrm{t}_{\text {tabel. }}$. Harga $\mathrm{t}_{\text {tabel }}$ didapatkan dari tabel distribusi $\mathrm{t}$ pada taraf signifikan $5 \%$ dengan derajat kebebasan $\mathrm{dk}=\mathrm{n}_{1}+\mathrm{n}_{2}-2$. Hasil uji-t dapat dilihat pada tabel 2 .

Tabel 2. Tabel Hasil Analisis Uji-t Data Kompetensi Pengetahuan IPS

\begin{tabular}{lcccccc}
\hline \multicolumn{1}{c}{ Sampel } & $\mathbf{N}$ & $\mathbf{D k}$ & $\bar{X}$ & $\mathbf{s}^{\mathbf{2}}$ & $\mathbf{t}_{\text {hitung }}$ & $\mathbf{t}_{\text {tabel }(\alpha=0,05)}$ \\
\hline Kelompok Eksperimen & 38 & \multirow{2}{*}{79} & 0,49 & 0,033 & \multirow{2}{*}{4,278} & 1,990 \\
Kelompok Kontrol & 43 & & 0,33 & 0,024 & & \\
\hline
\end{tabular}

Nilai rata-rata keterampilan menulis siswa kelompok eksperimen $\bar{X}=0,49$. Nilai rata-rata keterampilan menulis siswa kelompok kontrol $\bar{X}=0,33$. Berdasarkan hasil uji t diperoleh $\mathrm{t}_{\text {hitung }}=4,278>$ $t_{\text {tabel }}=1,990$. Sehingga $\mathrm{H}_{0}$ ditolak dan Ha diterima. Ini berarti terdapat perbedaan yang signifikan keterampilan menulis kelompok siswa yang dibelajarkan menggunakan model PAKEM berbasis tri hita karana dengan kelompok siswa yang dibelajarkan melalui pembelajaran konvensional pada siswa kelas IV SD Gugus Letkol Wisnu Denpasar Utara Tahun Ajaran 2017/2018.

Oleh karena itu, model PAKEM berbasis tri hita karana berpengaruh secara signifikan terhadap keterampilan menulis siswa kelas IV SD Gugus Letkol Wisnu Denpasar Utara Tahun Ajaran 2017/2018.

Nilai rata-rata keterampilan menulis siswa kelompok eksperimen $\bar{X}=0,49$. Nilai rata-rata keterampilan menulis siswa kelompok kontrol $\bar{X}=0,33$. Pada taraf signifikan $5 \%$ dan $\mathrm{dk}=79$ sehingga diperoleh $t_{\text {tabel }}=1,990$. Hasil analisis uji-t diperoleh $t_{\text {hitung }}=4,278$. Sehingga diperolah $t_{\text {hitung }}=4,278>t_{\text {tabel }}$ = 1,990 maka $\mathrm{H}_{0}$ ditolak dan $\mathrm{H}_{\mathrm{a}}$ diterima. Hal ini berarti terdapat perbedaan yang signifikan keterampilan menulis kelompok siswa yang dibelajarkan menggunakan model PAKEM berbasis tri hita karana dengan kelompok siswa yang kelompok siswa yang dibelajarkan melalui pembelajaran konvensional pada siswa kelas IV SD Gugus Letkol Wisnu Denpasar Utara Tahun Ajaran 2017/2018. Oleh karena itu, model PAKEM berbasis tri hita karana berpengaruh secara signifikan terhadap keterampilan menulis siswa kelas IV SD Gugus Letkol Wisnu Denpasar Utara Tahun Ajaran 2017/2018.

Dari perolehan keterampilan me-nulis pada kedua kelompok dapat diketahui bahwa kedua kelompok yang awalnya memiliki kemampuan setara, lalu setelah diberikan perlakuan pada kelompok eksperimen yakni model PAKEM berbasis tri hita karana, peroleh keterampilan menulis siswa pada kelompok eksperimen lebih baik di-bandingkan dengan keterampilan menulis siswa pada kelompok 
kontrol. Hal ini disebabkan oleh pembelajaran yang di-terapkan pada kelompok eksperimen memiliki banyak kelebihan.

Dengan menerapkan model PAKEM berbasis tri hita karana siswa mendapatkan kesempatan untuk berpartisipasi dalam berbagai aktivitas, kegiatan pembelajaran siswa dalam mengakses informasi, pengetahuan untuk dibahas dan dikaji dalam proses pembelajaran di kelas serta menciptakan suasana lingkungan belajar yang kondusif dibarengi dengan pengamalan nilai-nilai kearifan lokal tri hita karana, karena pembelajaran dirancang agar mengaktifkan siswa, mengembangkan kreativitas sehingga efektif namun tetap menyenangkan. Selain itu, pembelajaran didesain untuk melatih kemampuan serta keterampilan siswa dan pembelajaran tidak hanya dilakukan di dalam kelas tetapi juga dilaksanakan di luar kelas maupun di luar sekolah. Hal ini dapat membuat siswa memiliki pemikiran yang terbuka, imajinatif, dan inspirasi dalam mengembangkan pengetahuan siswa. Model pembelajaran ini memberikan pengaruh yang positif terhadap pembelajaran siswa, serta menjadikan siswa lebih aktif. Astami (2011) menyatakan kelebihan yang dimiliki oleh model PAKEM ini adalah (1) Model PAKEM memungkinkan anak untuk berinteraksi secara aktif, baik aktif dalam bertanya, mempertanyakan, dan mengemukakan pendapat, (2) Dalam PAKEM anak mampu belajar bekerja sama, (3) PAKEM mendorong anak untuk menghasilkan karya kreatif, (4) Model PAKEM mampu membangun kreativitas anak, dan (5) model PAKEM dapat menciptakan suasana pembelajaran yang menyenangkan. Wirawan (2011:2) mengatakan "tri hita karana merupakan tiga hal pokok yang menyebabkan kesejahteraan dan kemakmuran hidup manusia". Hasil penelitian ini didukung dengan teori penelitian yang dilakukan Cahyani (2015) dengan hasil penelitian yakni Peningkatan Keterampilan Menulis dengan Model PAKEM Melalui Teknik Menjadi Wartawan Junior di SD.

\section{Simpulan dan Saran}

Berdasarkan hasil penelitian dan pembahasan dapat disimpulkan bahwa model PAKEM berbasis tri hita karana berpengaruh secara signifikan terhadap keterampilan menulis siswa kelas IV SD Gugus Letkol Wisnu Denpasar Utara Tahun Ajaran 2017/2018. Nilai rata-rata keterampilan menulis siswa kelompok eksperimen $\bar{X}=0,49$. Nilai rata-rata keterampilan menulis siswa kelompok kontrol $\bar{X}=0,33$.

Hasil analisis uji-t dari penelitian yang telah dilakukan diperoleh $t_{\text {hitung }}=4,278$. Harga tersebut kemudian dibandingkan dengan harga $t_{\text {tabel }}$ dengan $\mathrm{dk}=79$ dan taraf signifikan 5\% sehingga diperoleh harga $t_{\text {tabel }}=1,990$, karena $t_{\text {hitung }}=4,278>t_{\text {tabel }}=1,990$ maka $H_{0}$ ditolak dan $H_{a}$ diterima. Ini berarti terdapat perbedaan yang signifikan keterampilan menulis kelompok siswa yang dibelajarkan menggunakan model PAKEM berbasis tri hita karana dengan kelompok siswa yang dibelajarkan melalui pembelajaran konvensional pada siswa kelas IV SD Gugus Letkol Wisnu Denpasar Utara Tahun Ajaran 2017/2018. Oleh karena itu, model PAKEM berbasis tri hita karana berpengaruh secara signifikan terhadap keterampilan menulis siswa kelas IV SD Gugus Letkol Wisnu Denpasar Utara Tahun Ajaran $2017 / 2018$.

Berdasarkan hasil penelitian, maka saran yang dapat diajukan adalah kepada, siswa berpartisipasi secara aktif dalam proses pembelajaran serta mempu meningkatkan motivasi dalam belajar sehingga dapat memberikan dampat postif bagi kompetensi pengetahuannya. Melihat hasil keterampilan menulis pada muatan materi bahasa Indonesia dengan penerapan model PAKEM berbasis tri hita karana, hendaknya guru menerapkan pada muatan materi bahasa Indonesia. Kepala Sekolah hendaknya menyediakan sarana yang maksimal untuk menunjang pembelajaran agar siswa semakin termotivasi untuk belajar dan memanfaatkan sarana tersebut untuk mengoptimalkan keterampilan siswa sehingga mutu sekolah menjadi lebih meningkat, dan peneliti bidang sejenis dengan dilakukannya penelitian ini, diharapkan peneliti lain melakukan penelitian lebih lanjut dengan menerapkan model PAKEM berbasis tri hita karana pada materi pembelajaran yang berbeda. Selain itu, dapat pula dilakukan penelitian lebih lanjut dengan menggunakan model PAKEM berbasis tri hita karana pada sumber data/sampel yang berbeda khususnya pada muatan materi bahasa Indonesia sehingga hasil penelitian benar-benar dapat menggambarkan keadaan sesungguhnya yang terjadi di lapangan.

\section{Daftar Rujukan}

Ani, Ni Kadek Kisri, I Wyn. Darsana, IGA. Agung Sri Asri. 2017. Pengaruh Model Pembelajaran Time Token Berbasis Tri Hita Karana terhadap Hasil Belajar IPS Siswa Kelas V. e-Journal PGSD Universitas Pendidikan Ganesha Mimbar PGSD Vol: 5 No: 2 Hal. 1-10. https://ejournal.undiksha.ac.id/index.php/JJPGSD/article/viewFile/11018/7069. Diakses tanggal: 30 Januari 2018 
Asmani, Jamal Ma'mur. 2011. 7 Tips Aplikasi PAKEM (Pembelajaran Aktif, Kreatif, Efektif, dan Menyenangkan. Yogyakarta: DIVA Press.

Astami, Ni Made Wira. 2016. "Penerapan Inkuiri Terbimbing Berbasis Tri Hita Karana Dapat Meningkatkan Sikap Sosial dan Kompetensi Pengetahuan IPS". e-Journal PGSD Universitas Pendidikan Ganesha Jurusan PGSD, Volume 4 (hlm. 1- 10), Tersedia pada https://ejournal.undiksha.ac.id/indx.php/JJPGSD/article/view/7250/4948 (di akses tanggal: 11 Januari 2018).

BSPN, 2016. Peraturan Menteri Pendidikan Nasional Nomor 22 Tahun 2006 Tanggal 23 Mei 2006 Standar Isi. Jakarta: Menteri Pendidikan Nasional.

Cahyani, Isah. 2015. "Peningkatan Keterampilan Menulis dengan Model PAKEM Melalui Teknik Menjadi Wartawan Junior di SD". Jurnal Pendidikan Sains Sosial dan Kemanusiaan, Vol.8(1), pp.39-54. Bandung, Indonesia: Minda Masagi Press, ISSN 1979-0112, Tersedia pada http://www. mindamasjournals.com/index.php/sosiohumanika/article/view/526, (di akses tanggal: 04 Januari 2018).

Dalman, H. 2016. Keterampilan Menulis. Jakarta: PT. RajaGrafindo Persada.

Farhrohman, Oman. 2017. Implementasi Pembelajaran Bahasa Indonesia di SD/MI. Primary Vol. 09 No. 01 Hal. 23-34. http://jurnal.uinbanten.ac.id/index.php/. Diakses tanggal: 30 Januari 2018

Khair, Ummul. 2018. Pembelajaran Bahasa Indonesia dan Sastra (BASASTRA) di SD dan MI. Jurnal $\begin{array}{lllllll}\text { Pendidikan } & \text { Dasar } & \text { Vol. } & 2 & \text { No. } & 1 & \text { Hal. }\end{array}$ http://journal.staincurup.ac.id/index.php/JPD/article/view/261. Diakses tanggal: 30 Januari 2018

Mulyasa. 2015. Pengembangan dan Implementasi Kurikulum 2013. Bandung: PT Rosdakarya.

Ngurah, Gusti Made. 1999. Buku Pendidikan Agama Hindu Untuk Perguruan Tinggi. Surabaya: Paramita

Permendikbud. 2014. Peraturan Menteri Pendidikan dan Kebudayaan Republik Indonesia Nomor 57 tahun 2014 Tentang Kurikulum 2013 Sekolah Dasar/Madrasah Ibtidaiyah. Jakarta: Kementerian Pendidikan dan Kebudayaan.

Purwanto,dkk. 2015. "Pembelajaran Pengelasan Las Busur Listrik Berbasis Project Based Learning Untuk Meningkatkan Keterampilan Berpikir Kritis Dan Hasil Belajar Siswa”. Jurnal Pendidikan Vokasi:Teori dan Praktek, ISSN 2302-285X, Tersedia pada http://jurnalmahasiswa.unesa.ac.id/index.php/pendidikan-vokasi-teori-danprak/article/view/13569/4816, (diakses tanggal: 30 Januari 2018)

Rusman, 2014. Model-Model Pembelajaran Edisi Kedua. Cetakan kelima. Jakarta: Rajawali Pers.

Sugiyono. 2014. Metodologi Penelitian Pendidikan. Bandung: Alfabeta Bandung.

Suharman, S. A., Pariabti P., dan Eko Hadi Sujiono. 2011. Penerapan Pendekatan Pakem (Pembelajaran Aktif Kreatif Efektif dan Menyenangkan) untuk Meningkatkan Hasil Belajar Fisika Siswa Kelas X2 $\begin{array}{lllllll}\text { SMA Negeri } 1 & \text { Pangkajene. JSPF Vol.7 No.2 Hal. 140-152. }\end{array}$ https://ojs.unm.ac.id/JSdPF/issue/view/165. Diakses tanggal: 30 Januari 2018.

Susanto, Ahmad. 2015. Teori Belajar dan Pembelajaran di Sekolah Dasar. Jakarta: Kencana Prenada Media Group.

Setyosari, Punaji. 2015. Metode Pelitian Pendidikan dan Pengembangan. Jakarta: Kencana Prenada Media Group.

Tarigan, Henry Guntur. 2013. Menulis Sebagai Suatu Keterampilan Berbahasa. Bandung: Angkasa. 
Wiana, Ketut. 2007. Tri Hita Karana Menurut Konsep Hindu. Surabaya : Paramita.

Wirawan, I Made Adi. 2011. Tri Hita Karana Kajian Teologi, Sosiologi dan Ekologi Menurut Veda. Surabaya: Paramita. 